\title{
ABCC6 wt Allele
}

National Cancer Institute

\section{Source}

National Cancer Institute. ABCC6 wt Allele. NCI Thesaurus. Code C116947.

Human ABCC6 wild-type allele is located in the vicinity of $16 \mathrm{p} 13.1$ and is approximately 75 $\mathrm{kb}$ in length. This allele, which encodes multidrug resistance-associated protein 6, plays a role in the active transport of drugs across the plasma membrane. Mutation of the gene is associated with pseudoxanthoma elasticum and generalized arterial calcification of infancy type 2. 